\title{
高電流密度の電氯銅製鍊に關する研究*
}

\author{
平 社 敬之助 \\ （束京帝國大學工學部治金學教室）
}

\begin{abstract}
.
In connection with the electrolytic extraction of copper, the detrimental cffect of iron sulphate as $\mathrm{Fe}^{+++}$in the electrolyte is so serious that the reduction of $\mathrm{Fe}^{+++}$to $\mathrm{Fe}^{++}$has hitherto been considered to be necessary for practrical success of the process. Therefore the iron in the elcetrolyte is generally started from ferrous state in low acid concentration.

In the author's process, however, the proper quantity of ferric stlphate is utilized with reference to the electrolysis in high acid electrolyte with higher current density in high current efficiency.

On the standpoint of the critical current density, the ferric sulphate is favorable for very high current density which can not be attained by the ferrous sulphate. Moreover the addition of small quantity of nitric acid is very effective to raise the critical current density.

When iron is in the electrolyte as $\mathrm{Fe}^{+++}$comparatively higher current efficiency is obtained by increasing the concentration of sulphuric acid in proper conditions of electrolysis. Lowering the equilibrium concentration of copper sulphate in $\mathrm{CuSO}_{4}-\mathrm{H}_{2} \mathrm{SO}_{4}-\mathrm{H}_{2} \mathrm{O}$ system by increasing the sulphuric acid is restored by the action of $\mathrm{Fe}^{+++}$to keep the higher concentration of copper which is favorable for the electrolysis wich high current density in fairly high eurrent efficiency.
\end{abstract}

梗概

濕式銅製鍊に關聯して浸出溶液よりの銅電解に於て必和混入する硫酸鐵の問題は最も重大でする が，著者の研究結果從來 $\mathrm{Fe}^{+++}$の惡影響在除くため態ふ還元設備を施し $\mathrm{Fe}^{++}$とする代りに $\mathrm{Fe}^{+++}$ の生成さる」㒒用ひ，低酸低電流密度の代りに高酸高電流密度の銅電解をなし， $\mathrm{Fe}^{+++}$の惡影響を極 度に少なくするのみならず,却つて之を利用し得る狀況を求むるてとが出來て。限界電流密度の見地上 りは $\mathrm{Fe}^{+++}$の適當なる你在のため $\mathrm{Fe}^{++} に$ に比し著しく高電流密度の電解を可能店らしむるもので，

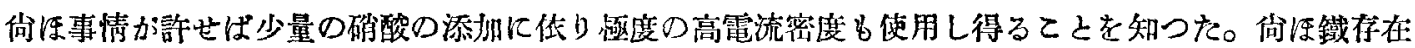
に於ける電流密度の影響に關する實驗例を示し，銅電解中に於りる第一鐵及び第二鐵の平衡的存在に 關し暹へ，普通の電解狀況に於ては $\mathrm{Fe}^{+++}: \mathrm{Fe}^{++}$の平衡比は著しく大にして大部分 $\mathrm{Fe}^{+++}$として

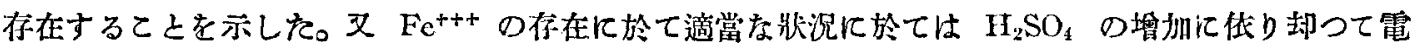
流效率を上显せしめ，高電流密度の䉓解に關眑して察引好紹果を認めた。

$\mathrm{CuSO}_{4}-\mathrm{H}_{2} \mathrm{SO}_{4}-\mathrm{H}_{2} \mathrm{O}$ 系平衡仿て $\mathrm{Fe}^{+++}$の添加飞传り，同一量の硫酸飞對し銅濃度を增大し，高 電流密度の電解に有利な影響を與ふることを紛つた。

本編は之等の諸項に關し概說したものである。

目次
1. 緒 言
4. 鐵存在に於ける銅析出電流効率に及涪す
2. 從隶の電氣收銅法に於ける電解液の特徵 電流密度の影響
3. 高電流犗度の電氣收銅法の要旨
5. 限界電流密度江及社す硫酸第 1 鐵及で第

* Rescarches on the Elcctrolytic Extraction of Copper with Inigh Current Density by KEINOSUKE HIRAKOSO (Department of Metallurgy, Tokyo Imperial University.) 


\section{2 鐵の影響}

6. 銅電解中に於ける第 1 鐵及び第 2 鐵の不

衡的存在

7. 限界電流密度几及添す硝酸つ影響

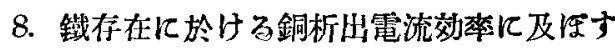

硫酸の影響

9. $\mathrm{CuSO}_{4}-\mathrm{H}_{2} \mathrm{SO}_{4}-\mathrm{H}_{2} \mathrm{O}$ の平衡飞及深す硫 酸第 2 鐵の影響

10. 總 括

\section{1. 緒言}

不溶性陽極（普通鉛）を用ふる電策銅製鍊汇關聯して

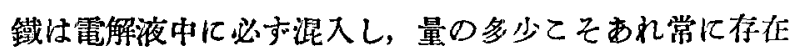
するもので，最す重要な問題であるが，之が硫酸第 2 鐵 の形てて存する時は電流效率を著しく降下せしめ，電氣 收銅の經濟的成功に對し大なる障害をなすと考へられて るる。然るに硫酸第 1 鐵の形に於て存在する時は電流效 率に對し殆んど影響はなく効率を降下せしめないと侾へ られてるる。從つて濕式電氣銅製鍊の湯合估第 2 鐵の瑟 影響を除去するため硫酸第 1 鐵に還元するこ之が推獎せ られ，從來一般法として實際用しられてるる。

郎ち現今電氣收銅法の原理牥鐵に關しては第 1 鐵とな すといふととに歸着してるる。然るに著者の研究に估れ ば從來の方法己全く反對に高電流密度の適用に關聯して 密る硫酸第 2 鐵として保有する電解法並び代事情が許せ ば少量の $\mathrm{HNO}_{3}$ を㧈ふ る方法がー居適切である といふふ結論に到着した。 本編沃於ては之等沉就 て少しく述べをいと思ふ。 况も本研究は目下進んで 實驗中であり，詳細の弡 表仗他の機會化铰るつる りである。

\section{2. 從來の電氣收銅法に於ける電解液の特徽}

從來銅電解に於ける鐵の影響に關しては，幾多の研 热 $^{(1)-(5)}$ があるが硫酸第 2 鐵の班に於て存在する時は電
流効率を著しく低下せしめ電解上致命的の障害なりと言 ふ結論に到着 L，乙の障害を除去する䉆，硫酸第 1 鐵に 還元する万法が用ひられてるる。Dr. F. Kern ${ }^{(5)}$ の實驗

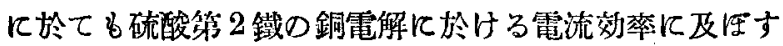
惡影響を求め，且つ硫酸第 1 鐵の形に存する場合壮殆ん ぞ影響なをて之を認めてるる。アホー製鍊所，チュキカ マタ製鍊所等に於ても早くより硫酸第 2 鐵としての卧影 響老認め，電解收銅老なす前飞先づ亞硫酸瓦斯を吹込み， 硫酸第 1 鐵に還元し，第 2 鐵の惡影響を除去することに 努めつけある。ての種の方法として有名なるはグリーン テワルト氏の電氣牧銅法 ${ }^{(6)}$ で $\mathrm{SO}_{2}$ 還元に特别な還元槽を 用ひ，向浩 $\mathrm{H}_{2} \mathrm{~S}$ で沈澱した硫化銅を第 2 鐡還元に利用 して居る。第 1 表江見る如〈現今電氣收銅法の筫際に於 ては總て先つ鐵柱第 1 鐵の形として電解を行ふととに䟿 着してみるっての事貫情第 1 鐵として存在する時は電流 燳式電氣收銅法の比較概要

\begin{tabular}{|c|c|c|c|c|c|c|c|c|}
\hline \multirow{2}{*}{$\begin{array}{c}\text { 工場 } \\
\text { 羿 }\end{array}$} & \multicolumn{2}{|c|}{ 電 } & 液 & \multicolumn{2}{|l|}{ 成 分 } & \multicolumn{2}{|c|}{ 電流揹 度 } & \multirow{3}{*}{ 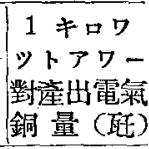 } \\
\hline & \multirow{2}{*}{$\begin{array}{l}\mathrm{Cu} \\
\% \\
\end{array}$} & \multirow{2}{*}{$\begin{array}{c}\text { Total Fe } \\
\because\end{array}$} & \multirow{2}{*}{$\begin{array}{l}\text { Ferrous } \\
\text { Iron } \%\end{array}$} & \multirow{2}{*}{$\begin{array}{c}\text { Ferric Iron } \\
\%\end{array}$} & \multirow{2}{*}{$\begin{array}{c}\mathrm{H}_{2} \mathrm{SO}_{4} \\
\% \\
\end{array}$} & \multirow{2}{*}{$\mathrm{A} / \mathrm{dm}^{2}$} & \multirow{2}{*}{$\mathrm{A} / \mathrm{ft}^{2}$} & \\
\hline 者 者 & & & & & & & & \\
\hline 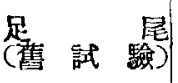 & $\begin{array}{c}3.3 \\
\text { (入液 })\end{array}$ & 1.50 & 1.31 & 0.19 & 0.93 & 0.9 & 8 & 0.18 \\
\hline 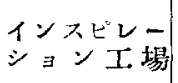 & $2.5 \sim 3.5$ & $1.5 \sim 2.5$ & $0.5 \sim 2.4$ & $0.1 \sim 1.0$ & $3.5 \sim 7.0$ & 1.6 & 15 & 0.30 \\
\hline 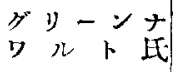 & 3.89 & 3.06 & 3.0 两为 & 0.1 队外 & 1.72 & 0.9 & 8 & $0.45 \sim 0.5$ \\
\hline $\begin{array}{l}\text { アリゾナ州バ } \\
\text { グダッド場 }\end{array}$ & 5.0 & 0.44 & 0.43 & 0.01 & 2.5 & 2.2 & 20 & 0.39 \\
\hline $\begin{array}{l}\text { アリゾナ州 } \\
\text { アホーエ場 }\end{array}$ & $2.42 \sim 2.70$ & $1.40 \sim 1.41$ & $0.97 \sim 1.30 \mid$ & $0.11 \sim 0.43$ & $2.16 \sim 2.33$ & 0.9 & 8 & 0.4 \\
\hline
\end{tabular}

效率つ_上飞影響艁く且つDepolarizer として利用し得る てと等得る。

\section{3. 高電流密度の電氣收銅法の要旨}

(5) Edward F. Kern: Trans. Am. Electrochem. Soc. XXXIII (1918) 131

(6) Greenawalt: Copyright by Amı. Inst. of Min. \& Met. Eng. Inc. (1924) 


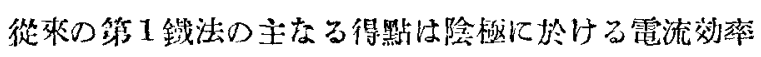
の降下を防くことさ陽柯に於ける Depolarizer しなり鉛 極の酸化を防ぐ點であるが，其の缺點とも考へらる」話 點は次の如くである。

（1）符 1 鐵還元のための特别なる設偖を裂すること

（2）陽極に於ては盛んに第2鐵となりつ」あるを以 つて之が陰極に移動せられ，再び效率を阼下せ しさへくく電解範图は極く小なること。列に低電 流密度の電解に於ては生成された第 2 鐵のため 電流效率著しく低下し一般に平均 $80 \%$ 位しか 得られざること。

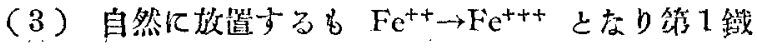
としての存在高乃不自然なるこよ。

（4）著者の研究に低れば限界電流密度を著しく下げ 電流密度を鈢度に上帠し得ざるとよ。

（5）陽極に發生する酸素を吸收し，硫酸の生成を娍 じ，との利归上不利なるとと。

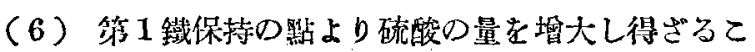
之o

著者は本研究に於て硫酸鐵の除去之共に晌潘高電流密 度の電解を行し，從隶つ低電流密度の缺陷を補塓するの みならず，從來硫酸第2鐵は電解上致命的口惡影響考及 ぼするの上のみ清へられて居つたのに反し，本研究の結 果却つて之を利用し得る事賽を求むる事が出來を。今本

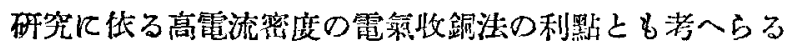
小諸點を列舉すれしば炏の如くである。

（1）高電流箈度の電解に依り同一座額任對し電解工 場を著しく減じ得ること。

（2）電解液の還元等のため特別なる設偖要せざる とと。

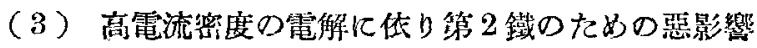

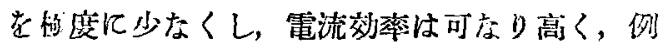

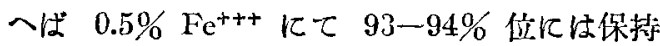
し得るこよ。

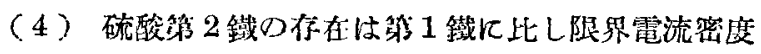
を著しく上帠せしめ，高電流密度の操棠を可能
ならしめ得るとと。

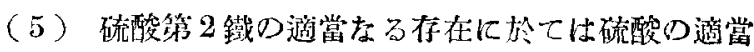

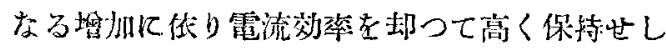
め)得るてと。

(6) 硫酸第 2 鐵の邀當なる存在は硫酸の增大住る

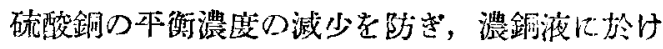
る電解を可能ならしめ得ること。

（7）硫酸第 2 鐵の存在は高電流密度の埸合比較的海

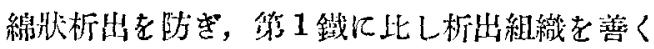
すること。

限界電流密度の兒地より從來の第 1 鐵注に於ては極媇 の高電流密度の電解に對しては不利である。えに反し第 2 鐵法汇位つて初めて適當なる高電流密度の電宷收銅を 筷行し得べきものである。份存少量の硝酸を抓ふること に依り骤度の高電流密度の電氣收銅が可能である。行も 总酸高電流密度の電解に俍り第 2 鐵の惡影響を極小なら

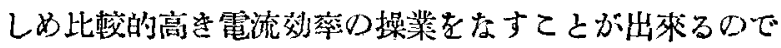
あつて一舉网得つ感がある。

即ち本電解收銅法の特微は從來の第 1 鐵法の代りに第 2 鐵法を用ひ，從來遊蹨硫酸の量は極く小なるに對し比 較的高酸度のものを川ひ，向症必要に應じ少量の硝酸

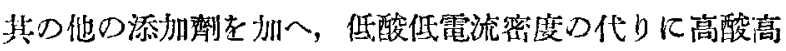
電流密度老箖代せんするものでする。

\section{4. 鐵存在に於ける銅析出電流効率に及ぼす 電流密度の影響}

第 1 表に示す如く現今濕式電氣收銅法の管際に於けっ 電流密度は比皎的低く，殊に舊來の大工場たるアホーコ： 場に於ては $0.9 \mathrm{~A} / \mathrm{dm}^{2}$ を箖用してるる。比較的最近に出 來たインスピレーション工場では $1.6 \mathrm{~A} / \mathrm{dm}^{2}$ より，バ ダダッド工場は $2.2 \mathrm{~A} / \mathrm{d}^{2}$ に上景してわる。かくの如く 最近の倾问は電流密庭を却るべく上是する傾向に進んで るるか，娜く普通の電氣精銅の場合の電流密伩に近き操 業をなすに至つたに過ぎない。

然るに電氣收銅に於ては電策精銅の場合亡異去り陽極 中の金銀等刀閒題なく，密る出來るだ電流䎹度を上是 せしむるうが得策な皆合が多いにも拘はら亦，却つて低 
電流滵度を採用しつ」あることは，沒出溶液中の不純物

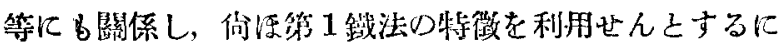
依るものであるが，又第 1 鐵法に依る限笊電流密展の著 しき低下は必然的汇電解操業を不可能ならしめ，高電流 密度つ電解に於ては重要な缺陷である。

本研究に於ては第 1 鐵法の代りに第 2 鐵法を利用せん とする方向に進んで居り，次項に述ぶる第2鐵に依る限

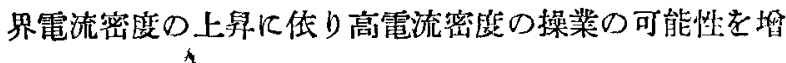
大することが出來てが，硫酸第2鐵の存在に於ては鋼析

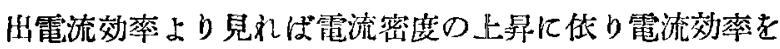

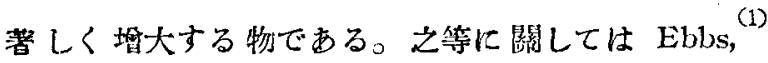

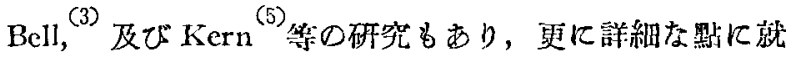

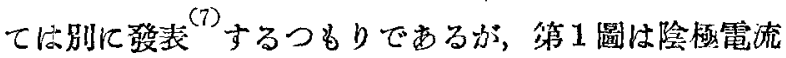

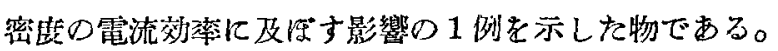
電解槽 $\mathrm{A}, \mathrm{B}, \mathrm{C}, \mathrm{D}$ 及び $\mathrm{E}$ 孝夫々最初は狀況を等しく， 且つ陽極の大さを等しく 2 佩合はをて $2.10 \mathrm{dm}^{2}$ ¿ L, た心陰極の有效析出面を知の则く變化して比較した結果 である。
A............2.10 $\mathrm{dm}^{2}\left(0.22 \mathrm{ft}^{2}\right)$
B...............49 dn $\mathrm{d}^{2}\left(0.160 \mathrm{ft}^{2}\right)$
C............1.12 $\mathrm{dm}^{2}\left(0.120 \mathrm{ft}^{2}\right)$
D............. $0.87 \mathrm{dm}^{2}\left(0.094 \mathrm{ft}^{2}\right)$
E............. $0.57 \mathrm{dm}^{2}\left(0.061 \mathrm{ft}^{2}\right)$

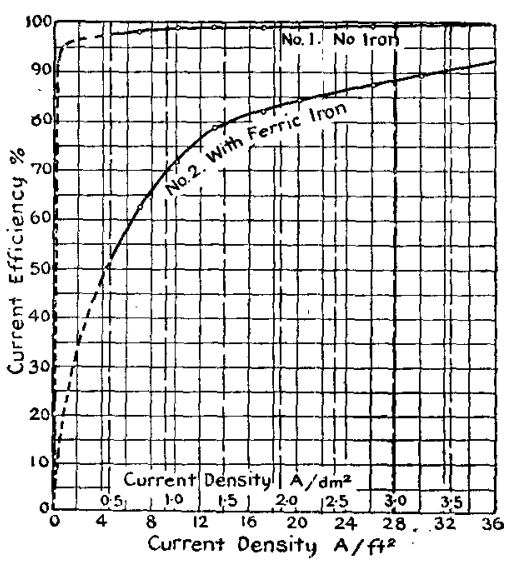

第 1 圖陰極電流密度の影響

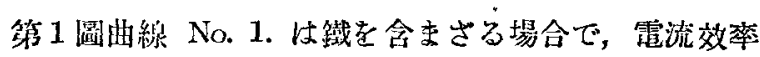
極めて高く電流密度の影響極めて少でするが，普连の湾

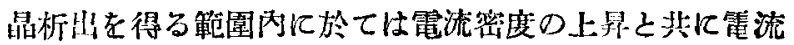
效率を增州することを知る。鐵が電解液中に仿する場合 は電流密度の影響は特に重大である。第 1 圖曲線 No. 2. は $\mathrm{Fe}^{+++}$として $0.90 \%, \mathrm{Fe}^{++} 0.08 \%, \mathrm{Cu} 2.63 \%$ を含 有する電解液 (溫度 $29^{\circ} \mathrm{C}$ ) 飞就き陰極電流密度を變化し て得られた結果であり，電流密庶の上昇之共に電流效率 を渚しく上昇するを㒫る。而して限界電流密度に達する 迄は大體電流密度の上景と共に電流效率を上昇すること を知る。從つて焙僥浸出其の他の處理に對して出來るた け電解液中に入り棑る鐵の量を少なからしむる（著者の 實驗に任れば比较的容易に之を售行することが出來る） と其㵝電流密度の電解に依り電流效禁は極く䯩く保持 することが出來る。

\section{5. 限界電流密度に及济す硳酸}

\section{第 1 鐵及び第 2 鐵の影響}

銅の電解に於ては電流密度を或程度以上上显せししれ

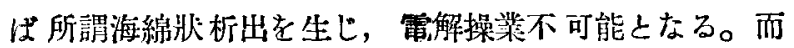
してての海阽枵析出と普通の密晶析出との間に限界があ

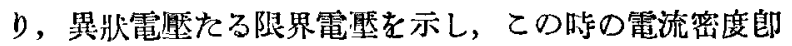
ち限界電流密度に達する程度を比蔽测定することに低り 良析出を得る電流密度の限度を比較することが出来る。 本研究に於ては從來の方法たる硫酸第 1 鐵を含む埸合 と本法に依る硫酸第 2 鐡を含さ場合とに垃て限界電流密

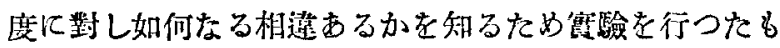
のである。

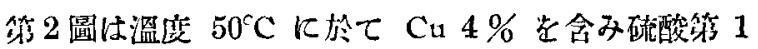

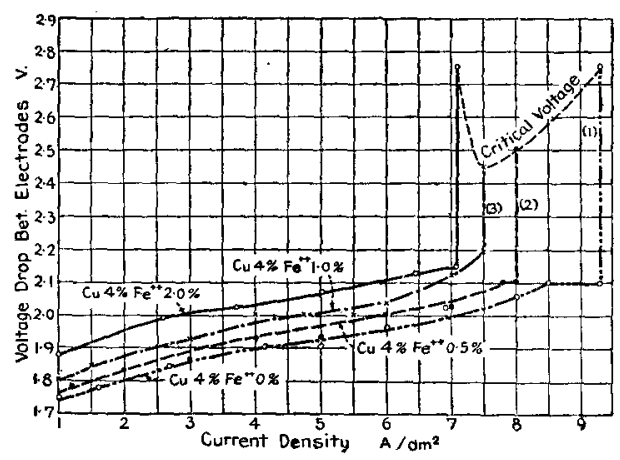

第 2 圆 限界電流櫁度に及ぼす硫酸第 1 鐵の影響 


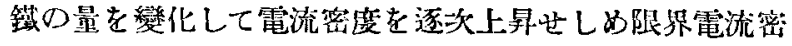
度に達せしめたものであるが，符 1 鐵の增玑したるもの

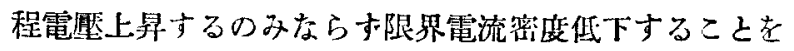
知る。

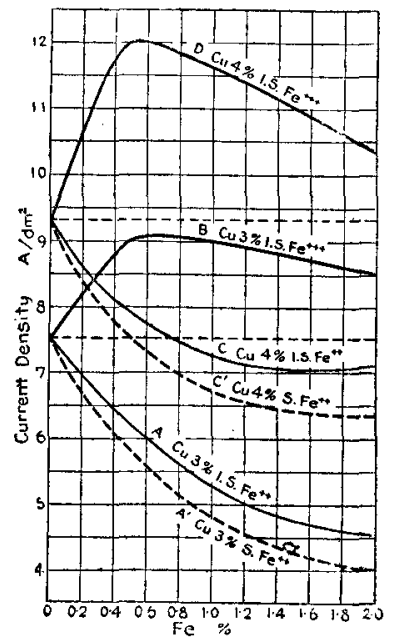

第 3 圆 限界電流密洨に皮添与磞酸 第 1 鐵及び第 2 鐵の影響

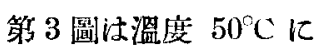
於て Ca3\% 及び $4 \%$ の場合の限界電流密度 に及守す鐵の影響を求 めたものであるが，(圖) 中 I.S. は不溶性鉛陽 㮌，S は埕陽極を用ひ た場合である）Cu 3\% のとき第 1 鐵として标 在する場合は A に示 す如く第 1 鐵の增加と 共限界電流密度索低 下せしめ,鐵なをとき の $7.5 \mathrm{~A} / \mathrm{dm}^{2}$ なるに跱し $\mathrm{Fe}^{++} 2.0 \%$ の時約 $4.5 \mathrm{~A} / \mathrm{dm}^{2}$

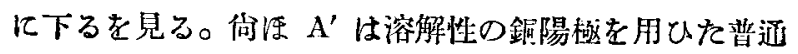
の電氣精銅の湯合に對寉するものであるが，一層限界電 流密度が低下してるる。そに反し第 2 鐵の列態にて存在 するときは B の曲線に示す如く, 鐵の增加と共に限界 電流密度を上显せしめ，0.5\% 附近に於て $9 \mathrm{~A} / \mathrm{dm}^{2}$ に澾 し略臤大となりそれより稍降下する傾向にある。

C は $\mathrm{Cu} 4 \%$ の場合， C’は同銅諹極の場合であり， 銅賑度上暴のため全體としての限界電流密度は上跳して みるが，第 1 鐵に依る限界電流密度の降下の有樣は阔栐 である。之に比し D の曲線は第 2 鐵として存する場合 であるが著しく限界電流密度を塤大し，殊に $\mathrm{Fe}^{+++} 0.5 \%$ 附近にて $12 \mathrm{~A} / \mathrm{dm}^{2}$ に羍し，嫩大に達してるる。

限界電流密度の紹對檤は電解状況に依り相造し, 極大 の黙の如きも變化するものであるが，第 1 鐵と第 2 鐵上 の限界電流密度に及济す影響の比較值は極めて顛著なる 相遶がある。

即ち硫酸第 2 鐵の場合は硫酸第 1 鐵の場合より限界電 流密度を一屡增大するてとを知る。從つて第 1 鐵法に比
し一層高き電流密度の操桑を可能ならしさる物でする。 而子 女解項記逃の如く高電流密度の電解に依り，電流效率 を上乎せしめ，其の上界の程度は低電流密度に依る生成 第2 鐵のための效率降下よりも大ならしさることを得べ く，電恇上景に依る損失を補ふことが出來る。

\section{6. 銅電解中に於ける第 1 鐵及び第 2 鐵の平衡的疜在}

鐵が電解液川に存在する時第 1 鐵及び第 2 鐵の濃度は 网極作用の結果電解中に絕え赫化し，電解時閆の經過 と共に兩極作用の相互影響の Resultant 晌つて進み， 電解液中の第 1 鐵及で第 2 鐵は遂には或る平衡的狀態に 達する。

而して兩極椙等しく 1 電解慒中 1 枚の狯極 1 校の陽梅 老用したる時銅の存在せさる場合は第 4 圖に示す如く第 1 鐵より始むるも第 2 鐵より始しるも電解㭙間の經過と 其に略法中心線に接近し, $\mathrm{Fe}^{+++}: \mathrm{Fe}^{++}$は大體 $1: 1$ にて

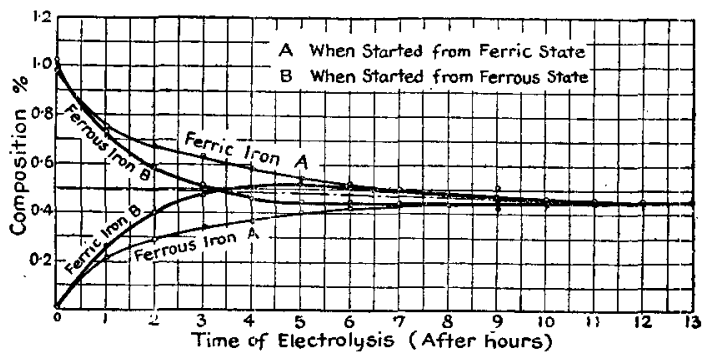

第 4 圆第 1 鐵及び第 2 緎の相互存在 其の1 鐵のみの場合

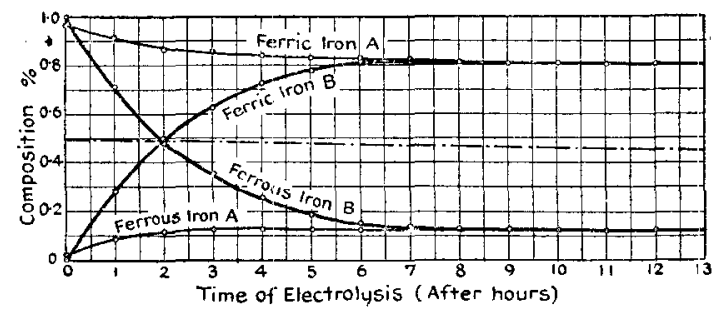

第 5 圖 第 1 鐵及び第 2 鐵の相互存在 其の2 Cu $0.5 \%$ の埸合

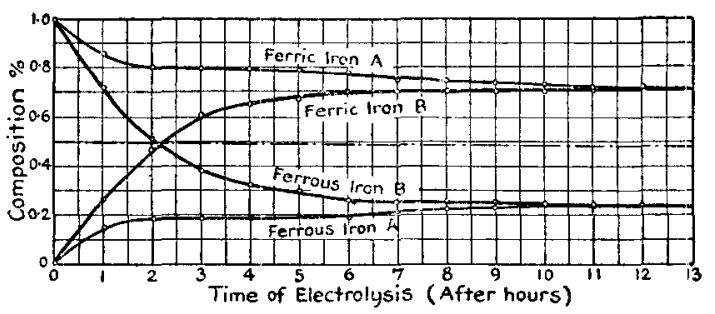

第 6 圆 第 1 鐵及で第 2 賳の相百存在 其の3 $\mathrm{Cu} 6 \%$ の埸合 
平衡に澾するを見る。

然るに銅の存する場合は本衡状態急變し，第 5 圖に示 す如く $\mathrm{Cu} 0.5 \%$ を含存する時は $\mathrm{Fe}^{+++} 0.72 \%$ に對し $\mathrm{Fe}^{++} 0.23 \%$ となり恒數に達し，平衡比 3.1 となり著し く第 2 鐵を增大するてとを知る。

この平衡比は濃度の塯大と共に嵝加し第 6 圆は $\mathrm{Cu}_{\mathrm{a}} 6$ \% の場合であるが $\mathrm{Fe}^{+++} 0.79 \%$ に對し， $\mathrm{Fe}^{++} 0.12 \%$

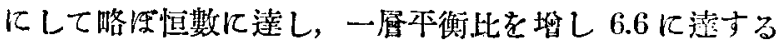
を見る。即ち若し電解を長く經續するならば鐵は砝んど 大部分は第 2 鐵として存在するてとななる。

而してての第 1 鐵及び第 2 鐵の相百變化の速度及び不 衡比は各硬の状况例へば兩極の相互大んさ，電解液の成

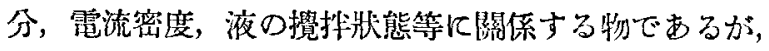
要するに普通の電解作業に於て若し自然のま」に放置す るならば，主として第2鐵として存在すると荐ふること が出來る。この第 2 鐵となる㑔向大なることは硫酸旌 1 鐵江還元する力法の铁點ですり，從來の筫作業に徴する も長く電解を繼䋶するてと能はす，第 2 鐵の生成のため 速か儿還元作用を䋊返寸必要を生品るのでするが，第 2 鐵として之を利用せんとする著者のオ法に路しては密乃

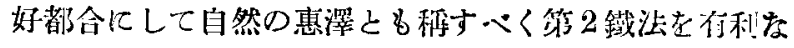
らしさる1素因である。

份電流泌度の䝬減に依る平衡比门變化に就ては，第

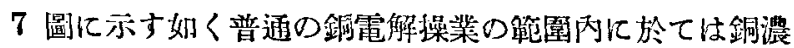

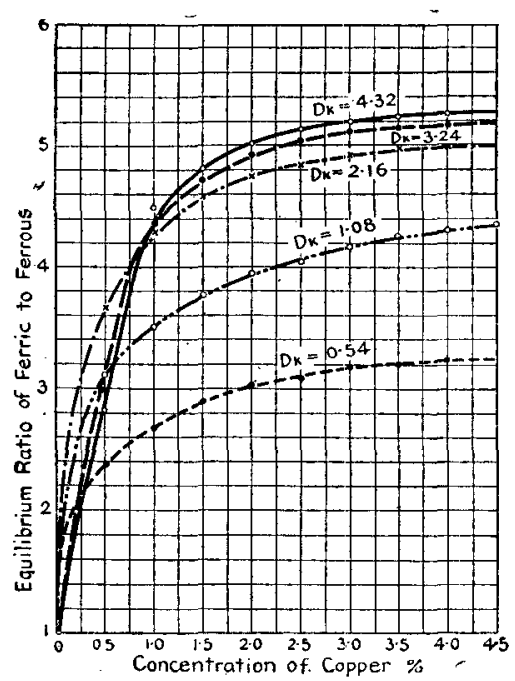

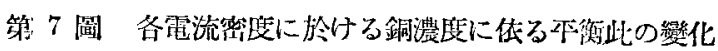

度の高き程及電流密度の高き程平衡比を坒大し行くこと 花知る。

即ち高電流密殿の電氣收銅に於ては第 1 鐵としての保 持一愿困難度るに比し，第 2 鐵として在せしむること は極もて容易なるてとを示してるる。

但し以上平衡的存在に達した $\mathrm{Fe}^{+++}$及び $\mathrm{Fe}^{++}$の含有 率は奎電解液の Resultant こして分析した結果であり，

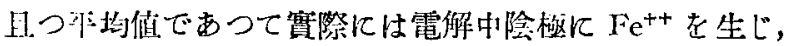
陽树には一居多く $\mathrm{Fe}^{+++}$として侍すると考へられる。

全践の增大は陵極の附近に於て $\mathrm{Fe}^{++}$の量を睤し限界 電流密度を降下せしさる $\mathrm{Fe}^{++}$の惡影響を扐展するのみ なら市 $\mathrm{Fe}^{+++}$に依る電流效率を低下せしさるものであ

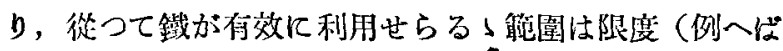
第 3 圆の結果に依れば Fe $0.5 \%$ 位)がある。

\section{7. 限界電流密度に及矿寸硝酸の影響}

銅電解に於ける限界電流密度に及疼す硝酸の影響 ${ }^{(8)}$ に 關しては硙酸を含またい場合，例へば $\mathrm{Cu} 4 \%, \mathrm{H}_{2} \mathrm{SO}_{4}$ $200 \mathrm{cc} / l(360 \mathrm{~g} / \mathrm{l})$ 溫度 $50^{\circ} \mathrm{C}$ D時限界電流密度 $5 \mathrm{~A} / \mathrm{dm}^{2}$ なるに反し浱确酸を少量 $10 \mathrm{cc} / \mathrm{l}$ 加ふっ時は $15 \mathrm{~A} / \mathrm{dm}^{2}$ $\left(140 \mathrm{~A} / \mathrm{ft}^{2}\right)$ 范山可なり良析出を得るのみなら和，限界電 流密度と目せらる。15 A に於てる特に急昇する所謂限 界電埾を現さず，析出組織に於ても普通の場合とは趣き を異にし，密晶組織より球跃の海綃师組織に至る間に特 に限界組鐡なく大體同樣な電着組織に於て逐次變化する を見る。第 8 圖の䁈線にて示す曲線 (3) は溫度 $60^{\circ} \mathrm{C}$ に

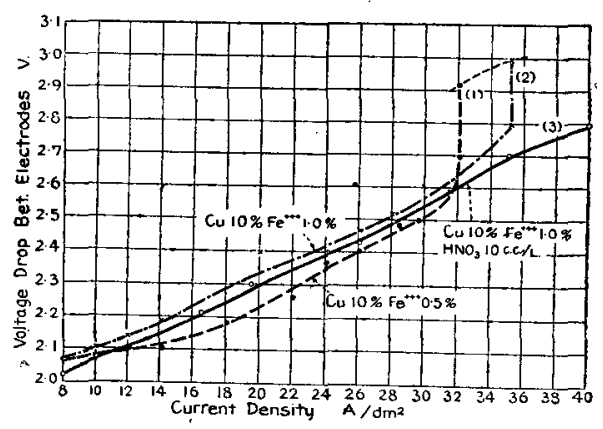

第 8 圖濃銅夜に於汗る高電流密度の䁈驗 於て銅濃度を極く高く $\mathrm{Cn} 10 \%$ と $\mathrm{Fe}^{+++} 1.0 \%$ を全 み而に䂤酸を $10 \mathrm{cc} / \mathrm{l}$ 㧈へた場合であるが，電流密度

(S) 平补敬之助：日鏣，580 (昭和 S) 635 
$40 \mathrm{~A} / \mathrm{dm}^{2}\left(372 \mathrm{~A} / \mathrm{ft}^{2}\right)$ に於ても未林全面海綿狀とならす。， 限暜電流密度に達しないてとを和つた。

てれは陽極より發生する酸素のための自然攪拢以外に は別に液の循環は行はない結果でする。從つて若し一属

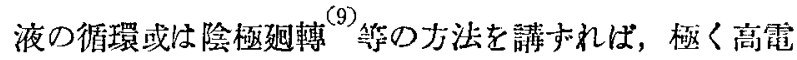

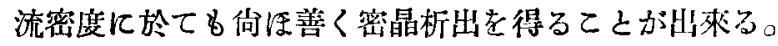

之等の結果に於ても明かなる如く限界電流密度に對す る硝酸の影響極めて有效䫏著ではあるが極く少量でな いと陰極に於ける銅を溶解し，電解の際b電流效率老下 げ，且つ陽極に於ても鉛を腐猞し，其の酸化作用を助辰 ナる倾问すり，從つて笔算降下も案外に上帠することが ある。

然し高電流密度の電氣收銅に對して海綿状析出を造ら ないために事情が許せば(陽極に珪化銅 ${ }^{(10)}$ を用ふれば

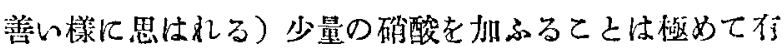
效適切なお法である。

鐵の存在する晹合は硝酸の添加は第2 鐵の生成圭助长 L，第 2 鐵法の限界電流密度に及汪す影響を一層碓保す るものである。

\section{8. 鐵存在に於ける銅新出電流効率に 及ぼす硫酸の影嶉}

電解液币に硫酸の狋在する事は液の電導度を垈版し， 電力の上には利益あれど，炏の反應に依り酸素の传在に 劫て金屬銅を溶解する女のと考へられる。

$\mathrm{Ca}+\mathrm{H}_{2} \mathrm{SO}_{4}+\mathrm{O}=\mathrm{CuSO}_{4}+\mathrm{H}_{2} \mathrm{O}$

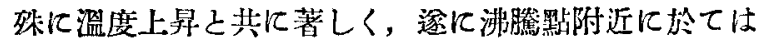
直接可なり良く溶解することいなる。從つて銅の析出電

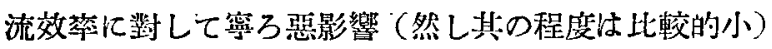
を及剧と考へられてみる。

殊に電茶收銅の場合は陽極に於て酸素墢生し，乙の酸 素が陰枚に達し前記溶蝕反應を助長する物と考へられ， 佾浪鐵の存在する場合硫酸の增为は炏の反應に依り硫酸 第 1 鐵上り硫酸第 2 鐵支生成する作用を助長し，

$2 \mathrm{FeSO}_{4}+\mathrm{H}_{2} \mathrm{SO}_{4}+\mathrm{O}=\mathrm{Fe}_{2}\left(\mathrm{SO}_{4}\right)_{3}+\mathrm{H}_{2} \mathrm{O}$

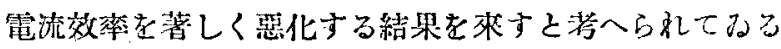
然るに本研究に於ては次に示す如く硫酸の增加が第 2

鐵の伱在汇於て電流效率の惡化を防ぐのみならず，却つ でを上界せしむるといふ興味ある結果を得ることが出 襟。

總て $\mathrm{Cu} 5 \% \mathrm{Fe}^{+++} 0.5 \%$ 全鐵 $0.5 \%$ 考合子䀀废 $14^{\circ} \mathrm{C}$ の溶液に就き硫酸の量を變化して比輘的骂時間(10 分) 䁈驗した結果で，最初2Aに於て行ひ次の實驗に於ては 電流をけげ 3 Aにしたものである。 $\mathrm{H}_{2} \mathrm{SO}_{4}$ の量に應ずる 電流效茶の關係を示壮代第 9 圖の如くである。

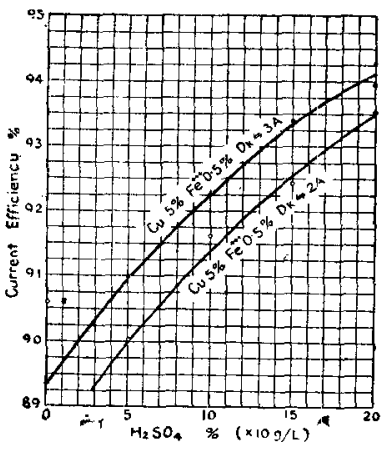

第 $\quad 9 \quad$ 圖

鐵存在に於ける硫酸の影㵿
これに依つて兄れば他 の状洒は殆んど同栐なる に拘らず，硫酸の垻加と 其に電流效率を上䊬する ことを知る。而して電流 密度を上帠をしめたる胩 は曲線上位にあり，電流 效率を上早することは研 に述べた通りであるが，

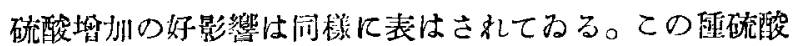
の好影響は電解液がきとして符 2 鐵として存する場合に 特に著しきもので，第 2 鐵の瑟影饗を防き，却つて之索 利用せんとする高電流密度の電氣收銅に關聯して興㶬方

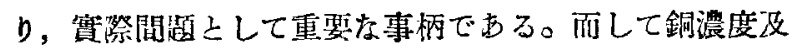
な゙硫酸の含有量に應じ利用し得へき $\mathrm{Fe}^{+++}$には限度す り，又 $\mathrm{Fe}^{+++}$の含有量に應じ之を利用し得へき電解狇況 に限度あり, 其の他の要項と共に最る適㗬なる電解狀況 を求さるこ上が出來る。尚詳綝は日本鐄業會誌昭和 9 年

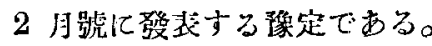

\section{9. $\mathrm{CuSO}_{4}-\mathrm{H}_{2} \mathrm{SO}_{4}-\mathrm{H}_{2} \mathrm{O}$ の平衡に及ぼす 硫酸第 2 鐵の影響}

前項に於て論区した如く適虽な $\mathrm{Fe}^{+++}$の存在に於て は硫酸の増扣に依り低酸の場合に比し電流效率を却つて

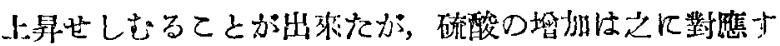

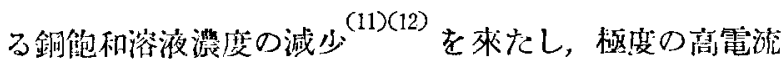

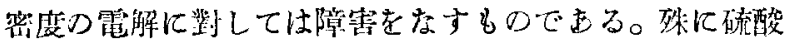

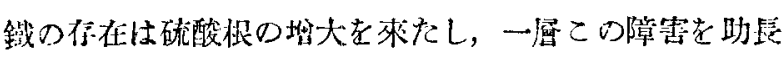
するものと考へられてるる。然るに著者の震驗結果化低 


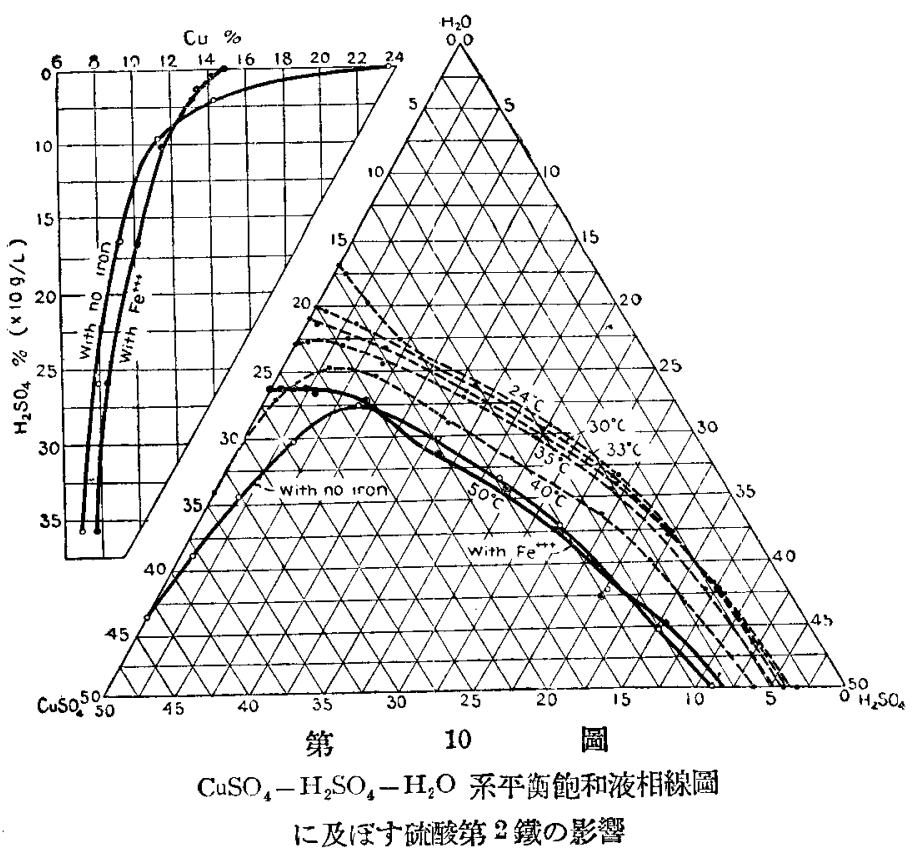

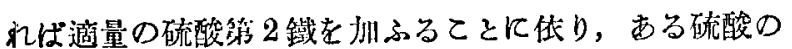

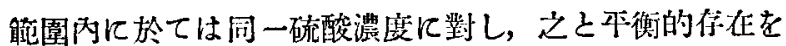
保つ銅漫度は却つて增大することを知つた。

符 10 圆に $\mathrm{CuSO}_{4}-\mathrm{H}_{2} \mathrm{SO}_{4}-\mathrm{H}_{2} \mathrm{O}$ 系本衡圖 ${ }^{(12)} \mathrm{K}$ 對 し硫酸第 2 鐵を加へた場合（罚度 $50^{\circ} \mathrm{C}$ ) の變化を表は したものである。包台單に $\mathrm{CuSO}_{4}-\mathrm{H}_{2} \mathrm{SO}_{4}-\mathrm{H}_{2} \mathrm{O}$ のみ ゆ場合に對し，硫酸第 2 鐵を $\mathrm{Fe}^{+++}$として $0.43 \%$ 添扣 したもので，ての結果に依れば $\mathrm{Fe}^{+++}$の存在のため本 衡緗圖上に於て純硫酸銅の場合上異なり殆んど山媔形を

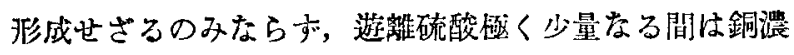
度の急增を裴はさない。而して硫酸濃度低き間 $\left(\mathrm{H}_{2} \mathrm{SO}_{4}\right.$ 約 7.5\%迄） $\mathrm{Fe}^{+++}$の存在のため純硫酸銅の場合上 り堸濃度を著しく低下せしもるに反し， $\mathrm{H}_{2} \mathrm{SO}_{4}$ 約 $7.5 \%$ 以上に於ては却つて銅湛度を擝大し好影響を及将してる

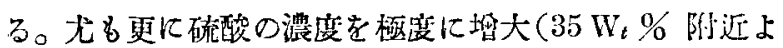
り）すれば再び低下し， $\mathrm{Fe}^{+++}$の好影響は表はれない。

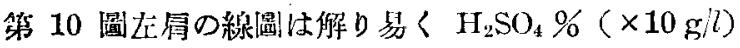
に對する銅 \%を示したるのである。而して以上の如を

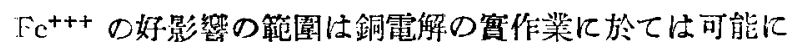
して却つて奶都合なるるのでむり，高電流密度の電氣銅 製鍊に關聯して有效な 1 原因をなすものである。
10. 總括 本編は濕式銅製鍊に關聯して電解液の特徽と して，從來の硫酸第 1 鐵法の代りに第 2 鐵法を 用し，從來の低酸低電流密姣の電解儿對し，高 酸高電流密度を用ひんとするもので，低電流密 店の電氣銅製鍊の缺陷を補墴与るのみならす，

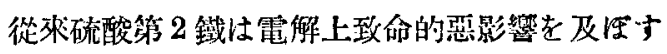
ものとのみ考へられて居つたのに反し，本研究 の結果次に列舉する諸點，其の他に於て却って 之を利用し，份汪少量の确酸の添扠依り從來 の方法では不可能ですつて極度つ高電流密度の 電解をる可能なるととを認めた。

（1）硫酸第 2 鐵の存在は第 1 鐵化比し限界電 流密度を著しく上帠せしめ, 高電流密度の操業を可 能ならしめ得るてと。

（2）高電流密度の電解任依り同一座銅飞對し電解工場 規模を著しく減じ得るとと。

（3）高電流密应の電解に位り第2 2 鐵のための惡影㗽を 嫩度飞少なくし，電流效率を高く保持し得ること。

（4）硫酸第 2 鐡の適當なる存在几於ては硫酸の適當な る增加低り電流效率老却つて高く保持せしめ得る rz。

（5）硫酸第 2 鐵の適當なる存在は硫酸の增加に低る硫 酸堸の平衡濃度の減少を防き，濃銅液に於りる電解 を可能ならしむるてと。

（6）硫酸第 2 鐵の適當なる存在惊第 1 鐵化比し限界電 流密度を上显する故高電流密度に於ては海綿狀とな るを防を゙，ての意味で析出組織を善くするてと。

（7）電解液の還元等のために從來の如く特別なる設借 を姴せざるてと。

而して本編に於ては先づ濕式電釆收銅に於て重要な關

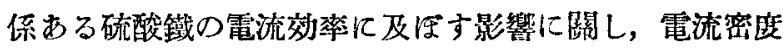
を變化した場合の賽驗例を舉げ，第 2 鐵の存在に於て は電流密度を上昇するてとの必要なる所以を明かにし，
(9) B.II. Strom: Eng. and min. 1., 134 (1933) 281 (11)J. M. Rell and W. C. Taber Phys. Chem., 12 (1908) 172
(10) Ifofman \& Hayward: metallurgy of Copper (1924) 300

平社敬之助：日鉒，49 (1933) 580 
更に限界電流密度の筫驗に低り $\mathrm{Fe}^{++}$の形に专る埸合概

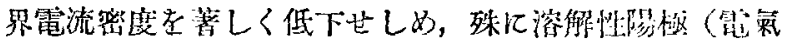

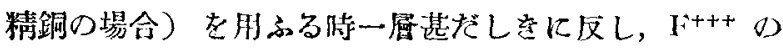
形に於て存するとをは却つて著しく之去沓せしむるこ とを見出L，硫酸第 2 鐵が高電流密度の電解儿對し有效

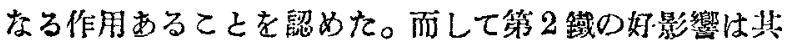
○会有量適當（例へば 0.5\%内外）なるとき特化著しく 1 の函大䛧を表はすてとを示した。

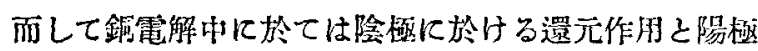
几於ける酸化作用との相互影蠁の結果臷の存在飞於て電 解を經續する場合法，第1䥫上り始むるも亦第 2 鐵より 始さるも銅漕度其つ他の電解壯況急變せざる限り最後に は符 2 鐵及び第 1 鐵の相互存在の比㤬全鐵量に應じ略在 一定と交り本衡几達するて上を認めた。この平衡的存在

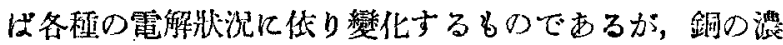
度の塯大子共に上昇し， $\mathrm{Fe}^{+++}: \mathrm{Fe}^{++}$の平衡此は腿めて

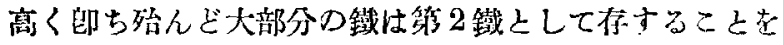
認めた。この見地より第 2 鐵の隐利月すること注自然り

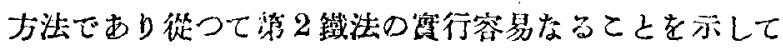
みる。

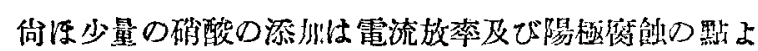
りすれば不利ですり，常に之を利用するととは困難です

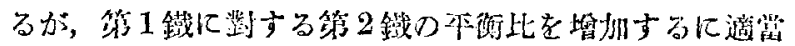
であり，限界電流密度を著しく上最せし内，筒霜流密度

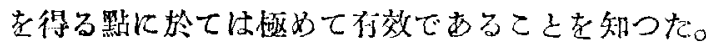

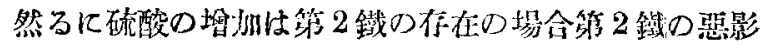
響を防を硫酸少なき場合上り電流效率上最することを認 めた。ての事實も從來米技見出されなかつた事であり，

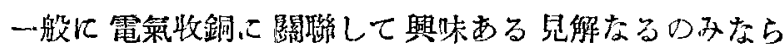
呮，本研究に於ける高電流密度D電氣收銅飞對し，1日 重慗な事项をなす名のでする。然し硫酸の塯扣㤌 $\mathrm{Ca}$ $\mathrm{SO}_{4}-\mathrm{H}_{2} \mathrm{SO}_{4}-\mathrm{H}_{2} \mathrm{O}$ 系习衡飞閣する研觉絬果之之共存す る銅飽和溶液の摆度を減少し，限界電流密度を低下する もので西るが，第2截の適當な存在のため本研究化示す

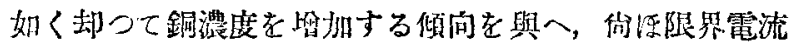

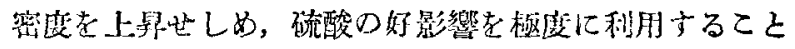
が㺫來るのである。

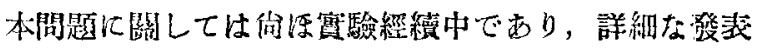
は他の機會に讓る。

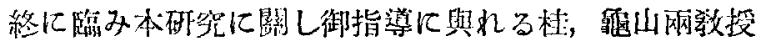

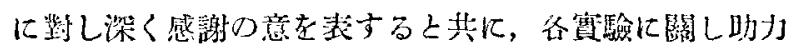

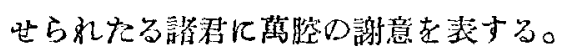

(昭利9佔 1 月 8 日受瑟) 